\title{
Mineralization of gellan gum hydrogels with calcium and magnesium carbonates by alternate soaking in solutions of calcium/magnesium and carbonate ion solutions
}

Lopez-Heredia, Marco A; apa, Agata; Reczyska, Katarzyna; Pietryga, Krzysztof; Balcaen, Lieve; Mendes, Ana Carina Loureiro; Schaubroeck, David; Van Der Voort, Pascal; Dokupil, Agnieszka; Plis, Agnieszka Total number of authors:

20

Published in:

Journal of Tissue Engineering and Regenerative Medicine

Link to article, DOI:

10.1002/term.2675

Publication date:

2018

Document Version

Peer reviewed version

Link back to DTU Orbit

Citation (APA):

Lopez-Heredia, M. A., apa, A., Reczyska, K., Pietryga, K., Balcaen, L., Mendes, A. C. L., Schaubroeck, D., Van Der Voort, P., Dokupil, A., Plis, A., Stevens, C. V., Parakhonskiy, B. V., Samal, S. K., Vanhaecke, F., Chai, F., Chronakis, I. S., Blanchemain, N., Pamua, E., Skirtach, A. G., \& Douglas, T. E. L. (2018). Mineralization of gellan gum hydrogels with calcium and magnesium carbonates by alternate soaking in solutions of calcium/magnesium and carbonate ion solutions. Journal of Tissue Engineering and Regenerative Medicine, 12(8), 1825-1834. https://doi.org/10.1002/term.2675

\section{General rights}

Copyright and moral rights for the publications made accessible in the public portal are retained by the authors and/or other copyright owners and it is a condition of accessing publications that users recognise and abide by the legal requirements associated with these rights.

- Users may download and print one copy of any publication from the public portal for the purpose of private study or research.

- You may not further distribute the material or use it for any profit-making activity or commercial gain

- You may freely distribute the URL identifying the publication in the public portal 


\section{Tissue Engineering and Regenerative Medicine}

\section{Mineralization of gellan gum hydrogels with calcium and magnesium carbonates by alternate soaking for bone regeneration applications}

\begin{tabular}{|c|c|}
\hline Journal: & Journal of Tissue Engineering and Regenerative Medicine \\
\hline Manuscript ID & TERM-17-0084.R1 \\
\hline Wiley - Manuscript type: & Research Article \\
\hline Date Submitted by the Author: & 27-Feb-2018 \\
\hline Complete List of Authors: & $\begin{array}{l}\text { Lopez Heredia, Marco; Universite Lille } 1 \\
\text { Lapa, Agata; AGH University of Science and Technology, Faculty of } \\
\text { Materials Science and Ceramics, Department of Biomaterials } \\
\text { Reczyńska, Katarzyna; AGH University of Science and Technology, Faculty } \\
\text { of Materials Science and Ceramics, Department of Biomaterials } \\
\text { Pietryga, Krzysztof; AGH University of Science and Technology, Faculty of } \\
\text { Materials Science and Ceramics, Department of Biomaterials } \\
\text { Balcaen, Lieve; Ghent University, Department of Analytical Chemistry } \\
\text { Mendes, Ana; Technical University of Denmark, National Food Institute } \\
\text { Schaubroeck, David; Imec, ELIS, Center for Microsystems Technology } \\
\text { (CMST) } \\
\text { Van der Voort, Pascal; Ghent University, Department of Inorganic } \\
\text { Chemistry } \\
\text { Dokupil, Agnieszka; Institute for Chemical Processing of Coal (ICHPW) } \\
\text { Plis, Agnieszka; Institute for Chemical Processing of Coal (ICHPW), } \\
\text { Stevens, Chris; University of Gent } \\
\text { Parakhonskiy, Bogdan; University of Gent, Molecular Biotechnology } \\
\text { Samal, Sangram K.; University Gent, Organic Chemistry } \\
\text { Vanhaecke, Frank; Ghent University, Department of Analytical Chemistry } \\
\text { Chai, Feng; University of Lille, College of Medicine } \\
\text { Chronakis, Ioannis; Technical University of Denmark, National Food } \\
\text { Institute } \\
\text { Blanchemain, Nicolas; Universite de Lille II } \\
\text { Pamuła, Elżbieta ; AGH University of Science and Technology, Faculty of } \\
\text { Materials Science and Ceramics, Department of Biomaterials } \\
\text { Skirtach, Andre; Ghent University, Molecular Biotechnology } \\
\text { Douglas, Timothy; Lancaster University, Engineering }\end{array}$ \\
\hline Keywords: & gellan gum, mineralization, composite, carbonate, magnesium, hydrogel \\
\hline
\end{tabular}




\section{Mineralization of gellan gum hydrogels with calcium and magnesium carbonates by}

alternate soaking in solutions of calcium/magnesium and carbonate ion solutions

Marco A. Lopez-Heredia ${ }^{1}$, Agata Lapa $^{2 \ddagger}$, Katarzyna Reczyńska ${ }^{2}$, Krzysztof Pietryga $^{2}$, Lieve Balcaen $^{3}$, Ana C. Mendes ${ }^{4}$, David Schaubroeck ${ }^{5}$, Pascal Van Der Voort ${ }^{6}$, Agnieszka Dokupil ${ }^{7}$, Agnieszka Plis $^{7}$, Chris V. Stevens ${ }^{8}$, Bogdan V. Parakhonskiy ${ }^{9,10}$, Sangram Keshari Samal ${ }^{11,12}$, Frank Vanhaecke ${ }^{3}$, Feng Chai ${ }^{1}$, Ioannis S. Chronakis ${ }^{4}$, Nicolas Blanchemain ${ }^{1}$, Elżbieta Pamuła $^{2}$, Andre G. Skirtach ${ }^{9,12}$, Timothy E.L. Douglas ${ }^{9,13,14 *}$

${ }^{1}$ Univ. Lille, INSERM, CHU Lille, U1008 - Controlled Drug Delivery Systems and Biomaterials, F-59000 Lille, France. ${ }^{2}$ Department of Biomaterials, Faculty of Materials Science and Ceramics, AGH University of Science and Technology, Kraków, Poland, ${ }^{3}$ Department of Analytical Chemistry, Ghent University, Krijgslaan 281 S12, 9000 Ghent, Belgium, ${ }^{4}$ Nano-BioScience Research Group, DTU-Food, Technical University of Denmark (DTU), Søltofts Plads, 227, 2800 Kgs. Lyngby, Denmark, ${ }^{5}$ Centre for Microsystems Technology (CMST), imec and Ghent University, Technologiepark - Zwijnaarde 15, 9052 Gent, Belgium ${ }^{6}$ Department of Inorganic Chemistry, COMOC, Ghent University, Krijgslaan, 281 S3, 9000, Ghent Belgium, ${ }^{7}$ Institute for Chemical Processing of Coal (ICHPW), ul. Zamkowa 1, 41-803 Zabrze, Poland, ${ }^{8}$ Department of Sustainable Organic Chemistry and Technology, Ghent University, Belgium, ${ }^{9}$ Department Molecular Biotechology, Ghent University, Coupure Links 653, 9000 Gent, Belgium, ${ }^{10}$ Shubnikov Institute of Crystallography, FSRC “Crystallography and Photonics” RAS, Moscow, Russia, ${ }^{11}$ Laboratory of General Biochemistry and Physical Pharmacy, Ghent University, Belgium, ${ }^{12}$ Centre for Nano- and Biophotonics, Ghent University, Belgium, ${ }^{13}$ Engineering Department, Gillow Avenue, Lancaster University, Lancaster, LA1 4YW, United Kingdom. ${ }^{14}$ Materials Science Institute (MSI), Lancaster University, Lancaster, LA1 4YW, United Kingdom. *Corresponding Author. Email: t.douglas@1ancaster.ac.uk 
1

2

3

4

5

6

7

8

9

†Current address : University of Erlangen-Nuremberg Department of Materials Science and Engineering Institute of Biomaterials (WW7) Cauerstr. 6, D-91058 Erlangen, Germany Keywords: Gellan gum hydrogels, calcium carbonate, magnesium, mineralization, composite Running head: Hydrogels mineralized with Ca/Mg-carbonate by alternate soaking

\begin{abstract}
Mineralization of hydrogels is desirable prior to applications in bone regeneration. $\mathrm{CaCO}_{3}$ is a widely used bone regeneration material and $\mathrm{Mg}$, when used as a component of calcium phosphate biomaterials, has promoted bone-forming cell adhesion and proliferation and bone regeneration. In this study, gellan gum (GG) hydrogels were mineralized with carbonates containing different amounts of calcium $(\mathrm{Ca})$ and magnesium $(\mathrm{Mg})$ by alternate soaking in, firstly, a calcium and/or magnesium ion solution and, secondly, a carbonate ion solution. This alternate soaking cycle was repeated five times. Five different calcium and/or magnesium ion

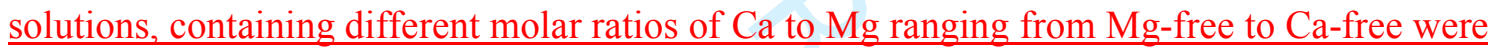
compared. Carbonate mineral formed in all sample groups subjected to the Ca:Mg elemental ratio in the carbonate mineral formed was higher than in the respective mineralizing solution. Mineral formed in the absence of $\mathrm{Mg}$ was predominantly $\mathrm{CaCO}_{3}$ in the form of a mixture of calcite and vaterite. Increasing the $\mathrm{Mg}$ content in the mineral formed led to the formation of magnesian calcite, decreased the total amount of the mineral formed and its crystallinity. Hydrogel mineralization and increasing $\mathrm{Mg}$ content in mineral formed did not obviously improve proliferation of MC3T3-E1 osteoblast-like cells or differentiation after 7 days.
\end{abstract}




\section{Introduction}

Hydrogels are gaining interest as biomaterials for bone regeneration. Enrichment of hydrogels with a mineral phase is considered desirable in order to promote bone healing in vivo after implantation into a bone defect site and to improve their mechanical properties (Gkioni et al., 2010). One such mineral phase known to promote bone regeneration is calcium carbonate $\left(\mathrm{CaCO}_{3}\right) . \quad \mathrm{CaCO}_{3}$ occurs in different crystalline forms including calcite, the most stable polymorph, and vaterite, the most thermodynamically unstable form under physiological conditions. There is evidence that enrichment of hydrogels with vaterite and/or calcite is beneficial for bone regeneration. Agarose hydrogels mineralized with a mixture of calcite and vaterite implanted into rat calvarial defects promoted bone regeneration (Suzawa et al., 2010). Calcite has been shown to be bioactive, i.e. it binds to bone directly in vivo (Fujita et al., 1991). Coatings of vaterite have stimulated formation of apatite upon incubation in simulated body fluid (SBF) (Maeda et al., 2007), suggesting that vaterite might display bioactivity in vivo. Several strategies to mineralize hydrogels with $\mathrm{CaCO}_{3}$ have been reported in the literature, including alternate soaking of hydrogels in solutions of calcium and carbonate ions (Ogomi et al., 2003, Suzawa et al., 2010). Calcite can be enriched with magnesium (Mg). Indeed, $\mathrm{Mg}$ is present in the calcareous exoskeletons of certain marine organisms (BorzeckaProkop et al., 2007, Nash et al., 2013, Diaz-Pulido et al., 2014). Naturally occurring calcite containing $30 \mathrm{~mol} . \% \mathrm{Mg}$ and synthetic calcites containing $39 \mathrm{~mol} . \% \mathrm{Mg}$ have been reported (Morse et al., 2007, Long et al., 2012). Hence, one can expect that $\mathrm{CaCO}_{3}$ biomaterials can be readily enriched with magnesium.

Recently inorganic calcium phosphate-based materials for bone regeneration have been enriched to promote adhesion and proliferation of bone-forming cells (Bracci et al., 2009, Douglas et al., 2016b, Landi et al., 2006). Hence, based on these studies, it was speculated in our study that $\mathrm{CaCO}_{3}$ enrichment with $\mathrm{Mg}$ could lead to similar positive biological effects. 


\section{Materials and Methods}

\subsection{Materials, production of GG hydrogel samples and mineralization by alternate soaking} All materials, including GG (GelzanTM CM, Product no. G1910, "Low-Acyl", molecular weight 200-300 kD), $\mathrm{CaCl}_{2}$ (No. 21074), $\mathrm{MgCl}_{2}, \mathrm{Na}_{2} \mathrm{CO}_{3}$ (No. 57795), were obtained from Sigma-Aldrich, unless stated otherwise. 
GG hydrogel samples in the form of discs were produced as described in earlier work (Douglas et al., 2014a, Douglas et al., 2014b). Briefly, $16 \mathrm{ml}$ of a $0.875 \%$ (w/v) GG solution in $\mathrm{ddH}_{2} \mathrm{O}$ was pre-heated to $90^{\circ} \mathrm{C} .4 \mathrm{ml}$ of a $0.15 \%(\mathrm{w} / \mathrm{v}) \mathrm{CaCl}_{2}$ solution was also pre-heated to $90^{\circ} \mathrm{C}$ and mixed with the $\mathrm{GG}$ solution. The resulting $20 \mathrm{ml} \mathrm{GG-CaCl}$ solution was cast in $10 \mathrm{~cm}$ Petri dishes at room temperature and allowed to set for $20 \mathrm{~min}$. The final GG and $\mathrm{CaCl}_{2}$ concentrations were $0.7 \%(\mathrm{w} / \mathrm{v})$ and $0.03 \%(\mathrm{w} / \mathrm{v})$, respectively. Using a hole punch, hydrogel samples in the form of discs of diameter $10 \mathrm{~mm}$ were cut out.

The hydrogel disc samples were soaked alternately at room temperature by immersion for 5 minutes in a calcium/magnesium solutions followed by immersion for 5 minutes in a carbonate solution. This cycle was repeated five times. Five different calcium/magnesium solutions containing different concentrations of $\mathrm{CaCl}_{2}$ and $\mathrm{MgCl}_{2}$ were used. The $\mathrm{Ca}: \mathrm{Mg}$ concentration ratios (all values $\mathrm{mmol} \cdot \mathrm{dm}^{-3}$ ) were as follows: 333:0, 250:83, 167:167, 83:250 and 0:333, respectively. Samples soaked in these calcium/magnesium solutions were denoted as $\mathrm{A}, \mathrm{B}, \mathrm{C}, \mathrm{D}$ and $\mathrm{E}$, respectively. The carbonate solution contained $333 \mathrm{mmol} \cdot \mathrm{dm}^{-3}$ of $\mathrm{Na}_{2} \mathrm{CO}_{3}$. An overview of the aforementioned solutions is given in Table 1.

\subsection{Determination of extent of mineral formation and physicochemical and morphological characterization by ATR-FTIR, XRD, SEM, EDS, ICP-OES, TGA and compressive testing} The dry mass percentage, i.e. the sample weight percentage attributable to polymer and mineral and not to water, served as a measure of the extent of mineral formation. Samples were weighed in the wet state after mineralization, dried at $60^{\circ} \mathrm{C}$ for $24 \mathrm{~h}$ and reweighed in the dry state. Dry mass percentage was defined as:

Dry mass $\%=($ weight after drying / weight in the wet state before drying $) * 100 \%$

Dry mass percentage measurements were made $(n=6)$ for all sample groups. 
A FTIR spectrometer (Spectrum BX, Perkin Elmer, Belgium) was used in the attenuated total reflectance mode (ATR) to obtain infrared spectra of the samples. The spectra were recorded over the wavenumber range $4000-550 \mathrm{~cm}^{-1}$ at 32 scans with a resolution of $4 \mathrm{~cm}^{-1}$.

XRD (ARL TM X'TRA, Thermo Scientific, Belgium) was performed at $40 \mathrm{kV}$ and $30 \mathrm{~mA}$ with a $\mathrm{Cu}-\mathrm{K}_{\alpha}$ radiation source $(\lambda=1.54 \mathrm{~nm})$. The slits used were: 0.6 and 1 at the source side and 0.6 and 0.2 at the detector side. Scans were made in continuous scan mode over a 2 Theta range from 10 to 50 with a step size of 2 Theta $=0.02$ degrees and a scan rate of $1.2 \mathrm{~s} / \mathrm{step}$. XRD Post processing analysis was performed with Highscore plus software 5 (PANalytical B.V., Netherlands) to study the crystallographic phase of the structures. The phase content analysis was performed using the semiquantative Rietveld method. The theoretical $\mathrm{CaCO}_{3}$ spectra were taken from the works of Sitepu (Sitepu, 2009) and Le Bail et al. (Le Bail et al., 2011) for calcite and vaterite, respectively. The theoretical spectra of sodium chloride and magnesium calcite were taken from Strel'tsov et al. (Strel'tsov et al., 1987) and Althoff (Althoff, 1977), respectively.

SEM and EDS were performed using a SEM JSM-5600 (JEOL, Japan) instrument. Dried samples were coated with a thin layer of gold for SEM imaging and with a thin layer of carbon for EDS analysis. Micrographs were obtained with a $20 \mathrm{kV}$ accelerating voltage.

The mass of elemental $\mathrm{Ca}, \mathrm{Mg}$ and sodium $(\mathrm{Na})$ present were determined by ICP-OES as described in previously (Gassling et al., 2013). In brief, samples were dissolved in $1 \mathrm{ml} 14 \mathrm{M}$ $\mathrm{HNO}_{3}$ (analytical grade, ChemLab, Belgium). For all sample groups, n=3.

TGA was performed with a TG 209 F1 Libra, coupled to a GC Agilent 7890B - MS Agilent 5977A, (NETZSCH-Gerätebau GmbH, Germany). Samples were placed in an $\mathrm{Al}_{2} \mathrm{O}_{3}$ crucible and heated from $313 \mathrm{~K}$ to $1273 \mathrm{~K}$ at a rate of $10 \mathrm{~K} / \mathrm{min}$ using argon at a flow rate of 25 $\mathrm{ml} / \mathrm{min}$ as a purge gas. Sample weights in the range $7.0-10.0 \mathrm{mg}$ were used. Weight was 
measured to an accuracy of $0.1 \mathrm{mg}$. Mass losses during the procedure were determined, as well as the initial and final temperatures of each stage of the degradation process.

A Texture Analyzer (TA-XT2i; Stable Micro Systems, UK), with a $5 \mathrm{~kg}$ load cell was used for the mechanical characterization of the hydrogel samples. The resistance of the samples to the compression of a metallic cylinder probe with a diameter of $15 \mathrm{~mm}$ was recorded. The pre-test speed was set up at $2 \mathrm{~mm} / \mathrm{s}$, the test speed at $1 \mathrm{~mm} / \mathrm{s}$, with a compression of the sample of $80 \%$ and the post-test speed at $1 \mathrm{~mm} / \mathrm{s}$. The experiments $(\mathrm{n}=6)$ were carried out at room temperature.

\subsection{Characterization of osteoblast-like cell attachment and growth}

The effect of hydrogels on MC3T3-E1 cell viability was assessed by direct contact. Before cell contact, hydrogels $(n=3)$ were immersed in $9 \mathrm{ml}$ cell culture medium $(\mathrm{CCM})(\alpha-\mathrm{MEM}$ with 10\% FBS (both Gibco, France) and $40 \mu \mathrm{g} / \mathrm{ml}$ gentamicin (Panpharma, France)) for $1 \mathrm{~d}$. Medium was removed and 40,000 cells $\left(\right.$ ATCC $^{\circledR}$ CRL-2594 ${ }^{\mathrm{TM}}$, USA) in a $55 \mu 1$ drop were seeded on hydrogels and allowed to attach for $2 \mathrm{~h}$, covered with medium and cultured at $37^{\circ} \mathrm{C}, 5 \% \mathrm{CO}_{2}$ and $100 \%$ humidity. After 1,3 and $7 \mathrm{~d}$, viability was measured by the AlamarBlue $^{\circledR}$ assay (ThermoFisher Scientific, France). Briefly, CCM was removed and $1 \mathrm{ml}$ $10 \%$ AlamarBlue ${ }^{\circledR}$ in CCM was added and incubated for $4 \mathrm{~h}$ in the dark. $150 \mu \mathrm{l}$ AlamarBlue ${ }^{\circledR}$ solution was recovered and fluorescence was measured (excitation $530 \mathrm{~nm}$, emission 590 nm). Cells seeded at different densities (500,000 to zero) served as standards. Hydrogels without cells were used as blanks.

\section{$\underline{2.4 \text { Characterization of osteoblast-like cell differentiation }}$}

$\underline{\text { The effect of hydrogels on MC3T3-E1 cell differentiation was assessed by direct contact. }}$ $\underline{\text { Before cell contact, hydrogels }(n=3) \text { were immersed in CCM as described in the previous }}$ 
subsection. Changes in CCM color in dependence of the sample group were observed. 40,000 $\underline{\text { cells were seeded on each sample as described in the previous subsection. }}$ $24 \mathrm{~h}$ later, after allowing the cells to reach at least 100\% confluency, the medium was $\underline{\text { replaced with osteogenic differentiation medium (ODM) containing } 1 \mu \mathrm{M} \text { dexamethasone, }}$ $\underline{\text { ascorbic acid }(50 \mu \mathrm{g} / \mathrm{ml}) \text { and } \beta \text {-glycerophosphate }(10 \mathrm{mM}) \text {. The osteogenic medium was }}$ completely replaced twice per week. Samples were analysed on day 7 and 14 days, after osteogenic induction. Cells were cultured in CCM on tissue culture polystyrene (TCPS) as a negative control. Cells were cultured in ODM on TCPS as a positive control. Hydrogels $\underline{\text { without cells were used as blanks. }}$

$\underline{\text { To evaluate activity of alkaline phosphatase (ALP) as a marker of osteogenic differentiation, }}$ $\underline{\text { the samples were rinced twice with Hank's Balanced Salt Solution (HBSS) and immersed in }}$ cell lysis buffer (CelLytic TM-M, C2978) $400 \mu \mathrm{l} /$ well at $4^{\circ} \mathrm{C}$ for $15 \mathrm{~min}$. Then, scraping the $\underline{\text { TCPS or hydrogel surface, the supernatants was collected in } 1.5 \mathrm{ml} \text { Eppendorf tubes. After a }}$ two-fold repeat freeze $\left(-80^{\circ} \mathrm{C}, 30 \mathrm{~min}\right)$ and defreeze $\left(37^{\circ} \mathrm{C}, 20 \mathrm{~min}\right)$ the lysed cells were centrifuged for $15 \mathrm{~min}$ at $16,000 \mathrm{~g}$ at $4^{\circ} \mathrm{C}$ to pellet the cellular debris. The supernatants were collected for the BCA and ALP assays. The evaluation was according to the formula: nmol pNP (measured) per ng (cell protein).

The ALP test was performed by mixing $50 \mu 1$ lysis solution with $50 \mu 1$ ALP Activity Assay Substrate solution (P5994) and incubating for $30 \mathrm{~min}$ at $37^{\circ} \mathrm{C}$. The reaction was stopped by adding $50 \mu 11 \mathrm{M} \mathrm{NaOH}$ solution and mixing on an orbital plate shaker for 30 seconds. Absorbance was measured at $405 \mathrm{~nm}$. The absorbance values were converted into nmol by $\underline{\text { means of standard curves. }}$

\subsection{Statistical Analysis}


Student's t-test was applied to determine statistical significance using Excel software. A twotailed unpaired t-test with $95 \%$ confidence interval was considered statistically significant if $p$ $<0.05(*), p<0.01(* *)$ and $p<0.001(* * *)$.

\section{Results and Discussion}

3.1 Physicochemical characterization of mineral formed: FTIR, XRD, SEM, EDS, TGA, ICPOES and compressive testing

All sample groups underwent mineralization. This was evident from the increase in opacity, which is shown in Supplementary Figure S1. Mineral was primarily formed in the outer part of the hydrogel. Groups B, C and D, i.e. groups with both $\mathrm{Ca}$ and $\mathrm{Mg}$, had a more whitish and deeper coating compared to group $\mathrm{A}$ and $\mathrm{D}$, i.e. groups with only $\mathrm{Ca}$ or $\mathrm{Mg}$.

\subsubsection{FTIR and XRD}

FTIR spectra of mineralized hydrogel samples are displayed in Figure 1a. Carbonate mineral was formed in all groups, as evidenced by the presence of bands at $860-870 \mathrm{~cm}^{-1}$, corresponding to $v_{2}$ antisymmetric bending of carbonate groups, as well as the broad band at approximately $1400 \mathrm{~cm}^{-1}$, which corresponds to $v_{3}$ antisymmetric stretching (Sato and Matsuda, 1969, Andersen and Brecevic, 1991, Xyla and Koutsoukos, 1989). In sample group $\mathrm{A}$, both calcite and vaterite, as bands corresponding to $v_{4}$ symmetric bending were detected at approximately 745 and $715 \mathrm{~cm}^{-1}$, which are typical for vaterite and calcite, respectively (Sato and Matsuda, 1969, Andersen and Brecevic, 1991, Xyla and Koutsoukos, 1989). In sample group B, the band at $745 \mathrm{~cm}^{-1}$, i.e. vaterite, disappeared. The band at approximately $715 \mathrm{~cm}^{-1}$, i.e. calcite, was less pronounced. No bands characteristic for $v_{4}$ symmetric bending, either vaterite or calcite, could be seen in sample groups C, D and E. The band at approximately $870-860 \mathrm{~cm}^{-1}$, corresponding to $v_{2}$ antisymmetric bending, became broader and less intense 
and decreased in wavenumber as $\mathrm{Mg}$ content in the mineralizing solution increased, i.e. in the direction $\mathrm{A} \rightarrow \mathrm{E}$. This suggests an increasing amorphicity in the direction $\mathrm{A} \rightarrow \mathrm{E}$. Characteristic bands for GG at approximately 1600 and $1030 \mathrm{~cm}^{-1}$, which were detected in previous works (Douglas et al., 2014a, Douglas et al., 2014b, Douglas et al., 2015), were not observed in any sample group. This demonstrates that a relatively small amount of GG was present relative to the carbonate mineral.

The results of XRD analysis are shown in Figure $\underline{1 b}$. Calcite and vaterite were both detected in sample group A. However, these peaks were much less evident in sample groups B and C and absent in sample groups D and E. This suggests increasing amorphicity. In sample groups C and D, the peak at 29.5, characteristic of the (104) plane of calcite, shifted slightly to a higher 2theta value, which is characteristic of magnesian calcite (Diaz-Pulido et al., 2014). Peaks characteristic for $\mathrm{NaCl}$ were observed in all samples. Peaks characteristic for GG were not observed in any sample group. Hence, the XRD results are in agreement with the FTIR results (Figure 1).

\section{$\underline{3.1 .2 S E M \text { and EDS }}$}

SEM images of mineral deposits formed in sample groups A, B, C, D and E are shown in Figure 2. In sample group A, both cube-like deposits characteristic of calcite and spherical deposits characteristic of vaterite were observed. This is consistent with the analysis by FTIR (Figure 1 $\underline{\mathrm{a}}$ ) and XRD (Figure $\underline{1 \mathrm{~b}}$ ). EDS analysis of sample group A is shown in Supplementary Figure S2. Different amounts of elemental Na were detected at different points. The presence of $\mathrm{Na}$ detected by ICP-OES is consistent with the presence of $\mathrm{NaCl}$ detected by XRD (Figure $\underline{1 b}$ ). It should be mentioned that it is unclear from EDS analysis if the $\mathrm{Na}$ is present as $\mathrm{NaCl}$ or $\mathrm{Na}_{2} \mathrm{CO}_{3}$. Deposits in sample group $\mathrm{B}$ were more amorphous and were present as larger spheres of approximate diameter $10 \mu \mathrm{m}$ and smaller spheres of approximate diameter $0.5 \mu \mathrm{m}$ (Figure 2). In sample group C, roughly spherical deposits of 
approximate diameter $5 \mu \mathrm{m}$ were seen. In addition, some network-like deposits were observed, which might be due to the GG polymer network, although this discussion must remain speculative. Such network-like deposits were also observed in sample groups D and E, along with small spherical deposits of approximate diameter less than $0.5 \mu \mathrm{m}$, and in the case of samples group E, spherical deposits of approximate diameter $5 \mu \mathrm{m}$, which were covered by network-like deposits. The observation of poorly defined spherical deposits in sample groups B, C, D and E suggests the presence of amorphous mineral, which is consistent with FTIR and XRD results (Figure 1). Unmineralized GG samples displayed a smooth surface devoid of deposits. EDS-based elemental mapping of sample groups $\mathrm{B}-\mathrm{E}$ revealed that $\mathrm{Ca}, \mathrm{Mg}$ and $\mathrm{Na}$ were distributed over the whole surface of the samples, with no regions of markedly higher $\mathrm{Ca}, \mathrm{Mg}$ or Na content (data not shown).

\section{$\underline{3.1 .3 T G A}$}

TGA results showing dependence of thermal degradation of sample groups A, B, C, D and E on temperature are shown in Figure 3 i-v. In sample group A, the first noteworthy mass decrease occurred between approximately $325 \mathrm{~K}$ and $425 \mathrm{~K}$. This can be ascribed to evaporation of loosely bound water. The second decrease occurred between approximately $475 \mathrm{~K}$ and $525 \mathrm{~K}$. This can be ascribed to evaporation of more tightly bound water. The main decrease occurred between approximately $875 \mathrm{~K}$ and $1025 \mathrm{~K}$. This corresponds to the decomposition of $\mathrm{CaCO}_{3}$ to $\mathrm{CaO}$ and $\mathrm{CO}_{2}$ (Frost et al., 2009). In sample group $\mathrm{B}$, the mass decreases between $325 \mathrm{~K}$ and $425 \mathrm{~K}$ and between $475 \mathrm{~K}$ and $525 \mathrm{~K}$ were more pronounced, suggesting a greater amount of bound water. This increase in bound water may be indicative of greater amorphicity or lower amount of mineral present. Furthermore, a mass decrease between approximately $525 \mathrm{~K}$ and $725 \mathrm{~K}$ was seen, which corresponds to degradation of GG polymer observed in previous work (Douglas et al., 2014a). In sample groups C and D the aforementioned mass decreases were more pronounced, suggesting greater amounts of bound 
water present and a higher proportion of GG polymer. In sample group D, the mass decrease between approximately $525 \mathrm{~K}$ and $725 \mathrm{~K}$ was particularly pronounced. The thermal decomposition profile of sample group E also exhibited the aforementioned mass decreases due to bound water, but the main thermal decomposition occurred in a lower temperature range, namely $600-750 \mathrm{~K}$. It is conceivable that this is due to thermal decomposition of a magnesium carbonate phase such as hydromagnesite, into $\mathrm{MgO}, \mathrm{CO}_{2}$ and $\mathrm{H}_{2} \mathrm{O}$, respectively (Hollingbery and Hull, 2010), however such discussion must remain speculative.

The dry mass percentages of the sample groups are shown in Figure $\underline{3}$ vi. Generally speaking, values decreased in the order $\mathrm{A} \approx \mathrm{B}>\mathrm{C}>\mathrm{D}>\mathrm{E}>>\mathrm{GG}$. It is known from previous work that the values for unmineralized GG samples range between approximately 0 and $2 \%$ (Douglas et al., 2016a). As expected, these values are considerably lower than those for mineralized samples. Elemental masses and molar amounts of $\mathrm{Ca}, \mathrm{Mg}$ and $\mathrm{Na}$ in the sample groups are presented in Figure $\underline{3}$ vii and viii, respectively. The results are consistent with the dry percentage measurements (Figure $\underline{3} \mathrm{vi}$ ). The elemental $\mathrm{Ca}: \mathrm{Mg}$ ratios in the mineralized hydrogels were higher than the respective $\mathrm{Ca}: \mathrm{Mg}$ ratios in the mineralization solutions. Hence, $\mathrm{Ca}$ was more readily incorporated into mineral formed than $\mathrm{Mg}$. Presumably, this is due to increased hydration of magnesium ions in solution and their slower dehydration relative to calcium ions, which hinders and decelerates their integration into mineral, as postulated previously (Martin and Brown, 1997). This preferential incorporation of Ca is also in agreement with studies on the effect of $\mathrm{Mg} / \mathrm{Ca}$ elemental ratio in seawater on the incorporation of $\mathrm{Mg}$ into marine invertebrate exoskeletons and non-skeletal precipitation (Ries, 2004, Stanley et al., 2002).

FTIR, XRD, SEM and TGA results (Figures 1, $2 \& \underline{3 i-v)}$ suggest that increasing the $\mathrm{Mg}$ content decreases crystallinity of the mineral formed. It is possible that the presence of $\mathrm{Mg}$ helps to stabilize the amorphous phase. Indeed, $\mathrm{Mg}$ has been reported to "poison" calcite 
formation (Folk, 1974), presumably by binding to the surface of calcite nuclei and inhibiting further crystal growth due to its residual water of hydration. Na was incorporated into all mineralized samples. This is consistent with the results of XRD (Figure $\underline{1 b}$ ) and EDS analysis. Less $\mathrm{Na}$ was present than $\mathrm{Ca}$ and $\mathrm{Mg}$ combined in all sample groups. The $\mathrm{Na}$ content increased in the order $\mathrm{A} \approx \mathrm{B}<\mathrm{C}<\mathrm{D}<\mathrm{E}$.

\subsubsection{Compressive testing}

The results of compressive testing are shown in Figure $\underline{3}$ ix. Generally resistance to compressive loading increased with increasing $\mathrm{Mg}$ content in the calcium/magnesium chloride mineralizing solution. Values for sample groups A and B were not markedly higher than those for unmineralized samples (GG). However, values for sample groups $\mathrm{C}$ and D were significantly higher than those for unmineralized samples and for sample group A. The highest values were observed for sample group E, which were significantly higher than those for unmineralized samples and sample groups A and B. The reasons for this remain unclear, as one would expect a higher amount of mineral present to lead to higher resistance to compressive loading. It is conceivable that the distribution and the structure of the mineral deposits may influence the mechanical properties. However, in the absence of further evidence, such discussion must remain highly speculative.

\subsection{Cell biological characterization with MC3T3-E1 osteoblast-like cells}

The results of the cell proliferation assay are shown in Figure $\underline{4}$. In general, mineralization did not have an appreciable positive influence on cell number. Unmineralized samples showed the highest cell number after 7 days. Of the mineralized sample groups, the highest values were seen for sample group E after 1 and 3 days, and for sample groups A and E after 7 days. Sample groups C and D showed markedly lower cell numbers than samples groups A and E at all time points. 
In previous work on GG hydrogels enzymatically mineralized with calcium phosphate (Douglas et al., 2014a), MC3T3-E1 cell adhesion rose markedly as a result of hydrogel mineralization with CaP. In another previous publication, ALP-enriched GG hydrogels were mineralized with five different mineralization solutions of varying $\mathrm{Ca}: \mathrm{Mg}$ molar ratios in order to assess the effect of $\mathrm{Mg}$ on the physiochemical and biological properties of the resulting composites (Douglas et al., 2014b). Incorporation of $\mathrm{Mg}$ into $\mathrm{CaP}$ mineral formed in GG hydrogels led to enhanced osteoblast-like cell adhesion and proliferation after 1 day and 11 days. This Mg-induced effect was independent of the crystallinity of the $\mathrm{CaP}$ formed (calcium-deficient apatite or amorphous $\mathrm{CaP}$ ).

In another study, enzymatic mineralization of GG with calcite and magnesian calcite lead to promotion of MC3T3-El osteoblast-like cell adhesion and proliferation after 1 day and 7 days (Douglas et al., in press). Hence, it is unclear why mineralization with carbonate mineral failed to markedly enhance cell proliferation in this study. It is possible that Mg-enhanced carbonate mineral is less effective at stimulating cell proliferation than $\mathrm{Mg}$-enhanced $\mathrm{CaP}$.

The biological effects of magnesium as a component of calcium carbonate may differ from its effects as a component of $\mathrm{CaP}$ materials in terms of the texture and solubility. The amount of Mg present may also play a role. In the absence of further data, such discussion must remain speculative.

The results of the osteogenic differentiation assay are shown in Figure 5. All sample groups were poorer at inducing ALP activity than TCPS after both 7 and 14 days. The reasons for $\underline{\text { this are unclear. Differences in stiffness and texture at the surface between TCPS and sample }}$ groups may play a role. Stiffer substrates are known to promote osteogenic differentiation (Boyan et al., 2003). No statistically significant differences were observed between groups A$\underline{\text { E and GG after } 7 \text { days. After } 14 \text { days, significantly superior values were observed on mineral }}$ sample groups B, C, D and E, which contain $\mathrm{Mg}$, than on sample group A, which is Mg-free. 
Improved differentiation of MC3T3-E1 cells has been reported on calcium phosphate substrates (Jiao and Wang, 2009, Zhao et al., 2013), however reports on osteogenic differentiation on calcium carbonate-based materials containing $\mathrm{Mg}$ are scarce. It is not inconceivable that the aforementioned differences in crystallinity between mineral formed in sample group A (most crystalline) and sample groups B, C, D, E (less crystalline) may play a role. However, due to the lack of previous studies of differentiation on calcium carbonate$\underline{\text { based materials of different crystallinities, such discussion must remain speculative. }}$

\section{Conclusion}

GG hydrogels were mineralized with an inorganic phase consisting of $\mathrm{Ca}, \mathrm{Mg}, \mathrm{Na}$ and carbonates by alternate soaking in solutions of calcium/magnesium chloride and sodium carbonate. In the absence of $\mathrm{Mg}$, the mineral formed was a combination of calcite, vaterite and $\mathrm{NaCl}$. As $\mathrm{Mg}$ content increased, the carbonate mineral formed became more amorphous, and a lower mass of mineral was formed. Ca was preferentially incorporated in comparison to Mg. Mineralization led to an increase in resistance to compressive loading. However the increase in resistance did not correlated with increasing mass of mineral present. It was not demonstrated that mineralization or the incorporation of $\mathrm{Mg}$ into mineral promoted osteoblast-like cell attachment. Further work should focus on in vivo studies to assess the ability of the mineralized hydrogels to support bone regeneration.

\section{Acknowledgement}

Timothy E.L. Douglas and Bogdan V. Parakhonskiy acknowledge the Research Foundation Flanders (FWO) for support in the framework of postdoctoral fellowships. Tom Planckaert 
and Pieter Zwaenenpoel are thanked for excellent technical assistance. Andre G. Skirtach thanks BOF (Bijzonder Onzderzoeksfonds) of Ghent University and FWO for support.

\section{Conflict of Interest, Ethical Approval, Original Publication and Author Contribution Statements}

The authors have no conflict of interest. No ethical approval was required for this study. No part of this work has been previously published or submitted for publication elsewhere.

The authors made the following contributions:

Marco A. Lopez-Heredia, Feng Chai and Nicolas Blanchemain performed cell experiments (Figures $4 \& 5$ ) as well as numerous preliminary cell experiments

Agata Łapa, Katarzyna Reczyńska, Krzysztof Pietryga and Elżbieta Pamuła designed the alternate soaking procedure for hydrogel mineralization, fabricated the samples (Figure S1), calculated dry mass percentage (Figure $\underline{3}$ vi) and performed considerable preliminary physicochemical characterization.

Lieve Balcaen and Frank Vanhaecke performed ICP-OES analysis (Figure $\underline{3}$ vii, viii)

Ana C. Mendes and Ioannis S. Chronakis devised, performed and interpreted mechanical characterization (Figure $\underline{3}$ ix).

David Schaubroeck performed SEM (Figure 2) and EDS (Figure S1) analysis Agnieszka Dokupil and Agnieszka Plis performed TGA (Figure $\underline{3} \mathrm{i}-\mathrm{v}$ )

Chris Stevens, Sangram Keshari Samal, Pascal Van der Voort and Bogdan Parakhonskiy performed XRD and FTIR measurements and analysed and interpreted the data (Figure 1) Timothy E.L. Douglas and Andre G. Skirtach devised, supervised and coordinated the study and wrote the manuscript.

\section{Tables}




\begin{tabular}{|c|c|c|c|}
\hline \multirow{3}{*}{$\begin{array}{c}\text { Sample } \\
\text { group }\end{array}$} & \multicolumn{2}{|c|}{ Concentrations in $\mathrm{Ca}^{2+} / \mathrm{Mg}^{2+}$ solution } & $\begin{array}{c}\text { Concentration in } \\
\mathrm{CO}_{3}{ }^{2-} \text { solution }\end{array}$ \\
\hline & $\mathrm{CaCl}_{2}$ & $\mathrm{MgCl}_{2}$ & $\mathrm{Na}_{2} \mathrm{CO}_{3}$ \\
\hline & $\left(\mathrm{mmol} \cdot d \mathrm{~m}^{-3}\right)$ & $\left(\mathrm{mmol} \cdot \mathrm{dm}^{-3}\right)$ & $\left(\mathrm{mmol} \cdot d \mathrm{~m}^{-3}\right)$ \\
\hline A & 333 & 0 & 333 \\
\hline $\mathrm{B}$ & 250 & 83 & 333 \\
\hline $\mathrm{C}$ & 167 & 167 & 333 \\
\hline $\mathrm{D}$ & 83 & 250 & 333 \\
\hline $\mathrm{E}$ & 0 & 333 & 333 \\
\hline
\end{tabular}

Table 1. Concentrations of solutions used to mineralize hydrogels in this study. Hydrogels were alternately soaked in $\mathrm{Ca}^{2+} / \mathrm{Mg}^{2+}$ solution and $\mathrm{CO}_{3}{ }^{2-}$ solution for 5 minutes.

\section{Figure Captions}

Figure 1. a) FTIR spectra of mineralized hydrogels. Top FTIR spectra from the region of 4000 to $500 \mathrm{~cm}^{-1}$. Middle region of 2000 to $500 \mathrm{~cm}^{-1}$. Bottom region from 1000 to $600 \mathrm{~cm}^{-1}$. b) XRD diffractograms of mineralized hydrogels for the different sample groups

Figure 2. SEM micrographs of mineralized hydrogels. Scale bar $=5 \mu \mathrm{m}$ in all cases except E $(10 \mu \mathrm{m})$. Absence of $\mathrm{Mg}$ generated a cubic structure (A) while the presence of $\mathrm{Mg}$ created microspheres between the GG structure. Some flake -like structure can also be observed. GG alone $(\mathrm{G})$ did not presented any obvious mineralization.

Figure $\underline{3}$. i-v: Thermogravimetric analysis of mineralized hydrogels A-E. Representative graphs showing residual mass percentage (TG) and rate of change of TG (DTG) are shown. vi: Dry mass percentage of mineralized (A-E) and unmineralized (GG) hydrogels. vii, viii: ICP-OES determination of elemental $\mathrm{Ca}, \mathrm{Mg}$ and $\mathrm{Na}$ present in mineralized hydrogels after drying. $\mu$ g element (vii) and $\mu$ mol element (viii) are shown. ix: Compressive testing of 
mineralized hydrogels. y-axis: force required to compress samples by $80 \%$. Error bars show standard deviation. Significances: $*: \mathrm{p}<0.05 ; * * \mathrm{p}<0.01 ; * * *: \mathrm{p}<0.001$

Figure $\underline{4}$. Proliferation of MC3T3-E1 osteoblast-like cells on mineralized (A-E) and unmineralized (GG) hydrogels. Error bars show standard deviation. Significances: *: $p<0.05$, $* *: \mathrm{p}<0.01, * * *: \mathrm{p}<0.001$

Figure 5. Osteogenic differentiation of MC3T3-E1 osteoblast-like cells on mineralized (A-E) and unmineralized (GG) hydrogels expressed as nmol alkaline phosphatase (ALP)/ng protein after 7 and 14 days. TCPS+: Tissue Culture Polystyrene with osteogenic differentiation $\underline{\text { medium. TCPS-: Tissue Culture Polystyrene without osteogenic differentiation medium. Error }}$ bars show standard deviation. Significances after $14 \mathrm{~d}: *: \mathrm{p}<0.05, * *: \mathrm{p}<0.01, * * *: \mathrm{p}<0.001$. $\underline{\text { Statistical significance between groups A-E and GG are indicated by letters. TCPS+ and }}$ $\underline{\text { TCPS- were statistically different to all samples group after both } 7 \text { and } 14 \text { days. No }}$ statistically significant differences were observed between groups A-E and GG after 7 days.

Supplementary Figure 1: Cross-sectional (top) and overhead (bottom) images of mineralized (A-E) hydrogels. Diameter $=10 \mathrm{~mm}$ in all cases.

Supplementary Figure 2: EDS analysis of mineralized hydrogel sample group A at three different points $(1,2,3)$.

\section{References}

ALTHOFF, P. L. (1977) Structural Refinements of Dolomite and a Magnesian Calcite and Implications for Dolomite Formation in Marine-Environment. American Mineralogist, 62, 772-783.

ANDERSEN, F. A. \& BRECEVIC, L. (1991) Infrared-Spectra of Amorphous and Crystalline Calcium-Carbonate. Acta Chem Scand, 45, 1018-1024. 
BORZECKA-PROKOP, B., WESELUCHA-BIRCZYNSKA, A. \& KOSZOWSKA, E. (2007) MicroRaman, PXRD, EDS and microscopic investigation of magnesium calcite biomineral phases. The case of sea urchin biominerals. Journal of Molecular Structure, 828, 80-90.

BOYAN, B. D., LOSSDORFER, S., WANG, L., ZHAO, G., LOHMANN, C. H., COCHRAN, D. L. \& SCHWARTZ, Z. (2003) Osteoblasts generate an osteogenic microenvironment when grown on surfaces with rough microtopographies. Eur Cell Mater, 6, 22-7.

BRACCI, B., TORRICELli, P., PANZAVOLTA, S., BOANINI, E., GIARDINO, R. \& BIGI, A. (2009) Effect of $\operatorname{Mg}(2+), \operatorname{Sr}(2+)$, and $\operatorname{Mn}(2+)$ on the chemico-physical and in vitro biological properties of calcium phosphate biomimetic coatings. J Inorg Biochem, 103, 1666-74.

DIAZ-PULIDO, G., NASH, M. C., ANTHONY, K. R. N., BENDER, D., OPDYKE, B. N., REYESNIVIA, C. \& TROITZSCH, U. (2014) Greenhouse conditions induce mineralogical changes and dolomite accumulation in coralline algae on tropical reefs. Nature Communications, 5.

DOUGLAS, T., WLODARCZYK, M., PAMULA, E., DECLERCQ, H., DE MULDER, E., BUCKO, M., BALCAEN, L., VANHAECKE, F., CORNELISSEN, R., DUBRUEL, P., JANSEN, J. \& LEEUWENBURGH, S. (2014a) Enzymatic mineralization of gellan gum hydrogel for bone tissue-engineering applications and its enhancement by polydopamine. $J$ Tissue Eng Regen Med, 8, 906-918.

DOUGLAS, T. E., DOKUPIL, A., RECZYNSKA, K., BRACKMAN, G., KROK-BORKOWICZ, M., KEPPLER, J. K., BOZIC, M., VAN DER VOORT, P., PIETRYGA, K., SAMAL, S. K., BALCAEN, L., VAN DEN BULCKE, J., VAN ACKER, J., VANHAECKE, F., SCHWARZ, K., COENYE, T. \& PAMULA, E. (2016a) Enrichment of enzymatically mineralized gellan gum hydrogels with phlorotannin-rich Ecklonia cava extract Seanol((R)) to endow antibacterial properties and promote mineralization. Biomed Mater, 11, 045015.

DOUGLAS, T. E., KRAWCZYK, G., PAMULA, E., DECLERCQ, H. A., SCHAUBROECK, D., BUCKO, M. M., BALCAEN, L., VAN DER VOORT, P., BLIZNUK, V., VAN DEN VREKEN, N. M., DASH, M., DETSCH, R., BOCCACCINI, A. R., VANHAECKE, F., CORNELISSEN, M. \& DUBRUEL, P. (2016b) Generation of composites for bone tissueengineering applications consisting of gellan gum hydrogels mineralized with calcium and magnesium phosphate phases by enzymatic means. J Tissue Eng Regen Med, 10, 938-954.

DOUGLAS, T. E. L., KRAWCZYK, G., PAMULA, E., DECLERCQ, H., SCHAUBROECK, D., BUCKO, M. M., BALCAEN, L., VAN DER VOORT, P., BLIZNUK, V., VAN DER VREKEN, N. M., VANHAECKE, F., DASH, M., DETSCH, R., BOCCACCINI, A. R., CORNELISSEN, R. \& DUBRUEL, P. (2014b) Generation of composites for bone tissue engineering applications consisting of gellan gum hydrogels mineralized with calcium and magnesium phosphate phases by enzymatic means. J Tissue Eng Regen Med.

DOUGLAS, T. E. L., LAPA, A., SAMAL, S. K., DEClERCQ, H. A., SCHAUBROECK, D., MENDES, A. C., VAN DER VOORT, P., DOKUPIL, A., PLIS, A., DE SCHAMPHELAERE, K., CHRONAKIS, I. S., PAMULA, E. \& SKIRTACH, A. G. (in press) Enzymatic, urease-mediated mineralization of gellan gum hydrogel with calcium carbonate, magnesium-enriched calcium carbonate and magnesium carbonate for bone regeneration applications. J Tiss Eng Regen Med.

DOUGLAS, T. E. L., PILARZ, M., LOPEZ-HEREDIA, M., BRACKMAN, G., SCHAUBROECK, D., BALCAEN, L., BLIZNUK, V., DUBRUEL, P., KNABE-DUCHEYNE, C., VANHAECKE, F., COENYE, T. \& PAMULA, E. (2015) Composites of gellan gum hydrogel enzymatically mineralized with calcium-zinc phosphate for bone regeneration with antibacterial activity. J Tiss Eng Regen Med, EPub 15.7.2015.

FOLK, R. L. (1974) Natural-History of Crystalline Calcium-Carbonate - Effect of Magnesium Content and Salinity. Journal of Sedimentary Petrology, 44, 40-53.

FROST, R. L., HALES, M. C. \& MARTENS, W. N. (2009) Thermogravimetric Analysis of Selected Group (Ii) Carbonateminerals - Implication for the Geosequestration of Greenhouse Gases. Journal of Thermal Analysis and Calorimetry, 95, 999-1005.

FUJITA, Y., YAMAMURO, T., NAKAMURA, T., KOTANI, S., OHTSUKI, C. \& KOKUBO, T. (1991) The bonding behavior of calcite to bone. J Biomed Mater Res, 25, 991-1003. 
GANTAR, A., DA SILVA, L. P., OLIVEIRA, J. M., MARQUES, A. P., CORRELO, V. M., NOVAK, S. \& REIS, R. L. (2014) Nanoparticulate bioactive-glass-reinforced gellan-gum hydrogels for bone-tissue engineering. Mater Sci Eng C Mater Biol Appl, 43, 27-36.

GASSLING, V., DOUGLAS, T. E., PURCZ, N., SCHAUBROECK, D., BALCAEN, L., BLIZNUK, V., DECLERCQ, H. A., VANHAECKE, F. \& DUBRUEL, P. (2013) Magnesium-enhanced enzymatically mineralized platelet-rich fibrin for bone regeneration applications. Biomed Mater, 8, 055001.

GKIONI, K., LEEUWENBURGH, S. C., DOUGLAS, T. E., MIKOS, A. G. \& JANSEN, J. A. (2010) Mineralization of hydrogels for bone regeneration. Tissue Eng Part B Rev, 16, 577-85.

HOLLINGBERY, L. A. \& HULL, T. R. (2010) The thermal decomposition of huntite and hydromagnesite-A review. Thermochimica Acta, 509, 1-11.

JIAO, M.-J. \& WANG, X.-X. (2009) Electrolytic deposition of magnesium-substituted hydroxyapatite crystals on titanium substrate. Materials Letters, 63, 2286-2289.

LANDI, E., TAMPIERI, A., MATTIOLI-BELMONTE, M., CELOTTI, G., SANDRI, M., GIGANTE, A. \& FAVA, P. (2006) Biomimetic Mg- and Mg, CO3-substituted hydroxyapatites: synthesis, characterization and in vitro behaviour. J Eur Ceram Soc, 26, 2593-601.

LE BAIL, A., OUHENIA, S. \& CHATEIGNER, D. (2011) Microtwinning hypothesis for a more ordered vaterite model. Powder Diffr, 26, 16-21.

LEE, S. K., SILVA-CORREIA, J., CARIDADE, S. G., MANO, J. F., OLIVEIRA, J. M., KHANG, G. $\&$ REIS, R. L. (2012) Evaluation of different formulations of gellan gum-based hydrogels for tissue engineering of intervertebral disc. J Tissue Eng Regen Med, 6, 44-44.

LONG, X., NASSE, M. J., MA, Y. R. \& QI, L. M. (2012) From synthetic to biogenic Mg-containing calcites: a comparative study using FTIR microspectroscopy. Physical Chemistry Chemical Physics, 14, 2255-2263.

MAEDA, H., MAQUET, V., KASUGA, T., CHEN, Q. Z., ROETHER, J. A. \& BOCCACCINI, A. R. (2007) Vaterite deposition on biodegradable polymer foam scaffolds for inducing bone-like hydroxycarbonate apatite coatings. J Mater Sci Mater Med, 18, 2269-73.

MARTIN, R. I. \& BROWN, P. W. (1997) The effects of magnesium on hydroxyapatite formation in vitro from CaHPO4 and Ca4(PO4)2O at 37.4 degrees C. Calcif Tissue Int, 60, 538-46.

MORSE, J. W., ARVIDSON, R. S. \& LUTTGE, A. (2007) Calcium carbonate formation and dissolution. Chem Rev, 107, 342-81.

NASH, M. C., OPDYKE, B. N., WU, Z. W., XU, H. F. \& TRAFFORD, J. M. (2013) Simple X-Ray Diffraction Techniques to Identify Mg Calcite, Dolomite, and Magnesite in Tropical Coralline Algae and Assess Peak Asymmetry. Journal of Sedimentary Research, 83, 1085-1099.

OGOMI, D., SERIZAWA, T. \& AKASHI, M. (2003) Bioinspired organic-inorganic composite materials prepared by an alternate soaking process as a tissue reconstitution matrix. $J$ Biomed Mater Res A, 67, 1360-6.

PIMENTA, D. R., SILVA-CORREIA, J., CARIDADE, S. G., SOUSA, R. A., OLIVEIRA, J. M., MANO, J. F. \& REIS, R. L. (2011) Novel Gellan Gum Hydrogels for Tissue Engineering of Intervertebral Disc. Int J Artif Organs, 34, 703-703.

RIES, J. B. (2004) Effect of ambient $\mathrm{Mg} / \mathrm{Ca}$ ratio on $\mathrm{Mg}$ fractionation in calcareous marine invertebrates: A record of the oceanic $\mathrm{Mg} / \mathrm{Ca}$ ratio over the Phanerozoic. Geology, 32, 981984.

SATO, M. \& MATSUDA, S. (1969) Structure of Vaterite and Infrared Spectra. Zeitschrift Fur Kristallographie Kristallgeometrie Kristallphysik Kristallchemie, 129, 405-\&.

SILVA-CORREIA, J., OLIVEIRA, J. M., CARIDADE, S. G., OLIVEIRA, J. T., SOUSA, R. A., MANO, J. F. \& REIS, R. L. (2011) Gellan gum-based hydrogels for intervertebral disc tissueengineering applications. J Tissue Eng Regen Med, 5, E97-E107.

SITEPU, H. (2009) Texture and Structural Refinement Using Neutron Diffraction Data from Molybdite (MoO3) and Calcite (CaCO3) Powders and a Ni-Rich Ni50.7Ti49.30 Alloy. Powder Diffr, 24, 315-326.

STANLEY, S. M., RIES, J. B. \& HARDIE, L. A. (2002) Low-magnesium calcite produced by coralline algae in seawater of Late Cretaceous composition. Proc Natl Acad Sci U S A, 99, 15323-6. 
STREL'TSOV, V. A., TSIREL'SON, V. G., OZEROV, R. P. \& GOLOVANOV, O. A. (1987) Electronic and Thermal Properties of Ions in CaF2: Regularized Least Squares Treatment. Kristallografiya, 33, 90-97.

SUZAWA, Y., FUNAKI, T., WATANABE, J., IWAI, S., YURA, Y., NAKANO, T., UMAKOSHI, Y. \& AKASHI, M. (2010) Regenerative behavior of biomineral/agarose composite gels as bone grafting materials in rat cranial defects. J Biomed Mater Res A, 93, 965-75.

XYLA, A. G. \& KOUTSOUKOS, P. G. (1989) Quantitative-Analysis of Calcium-Carbonate Polymorphs by Infrared-Spectroscopy. Journal of the Chemical Society-Faraday Transactions I, 85, 3165-3172.

ZHAO, S. F., JIANG, Q. H., PEEL, S., WANG, X. X. \& HE, F. M. (2013) Effects of magnesiumsubstituted nanohydroxyapatite coating on implant osseointegration. Clin Oral Implants Res, 24 Suppl A100, 34-41. 

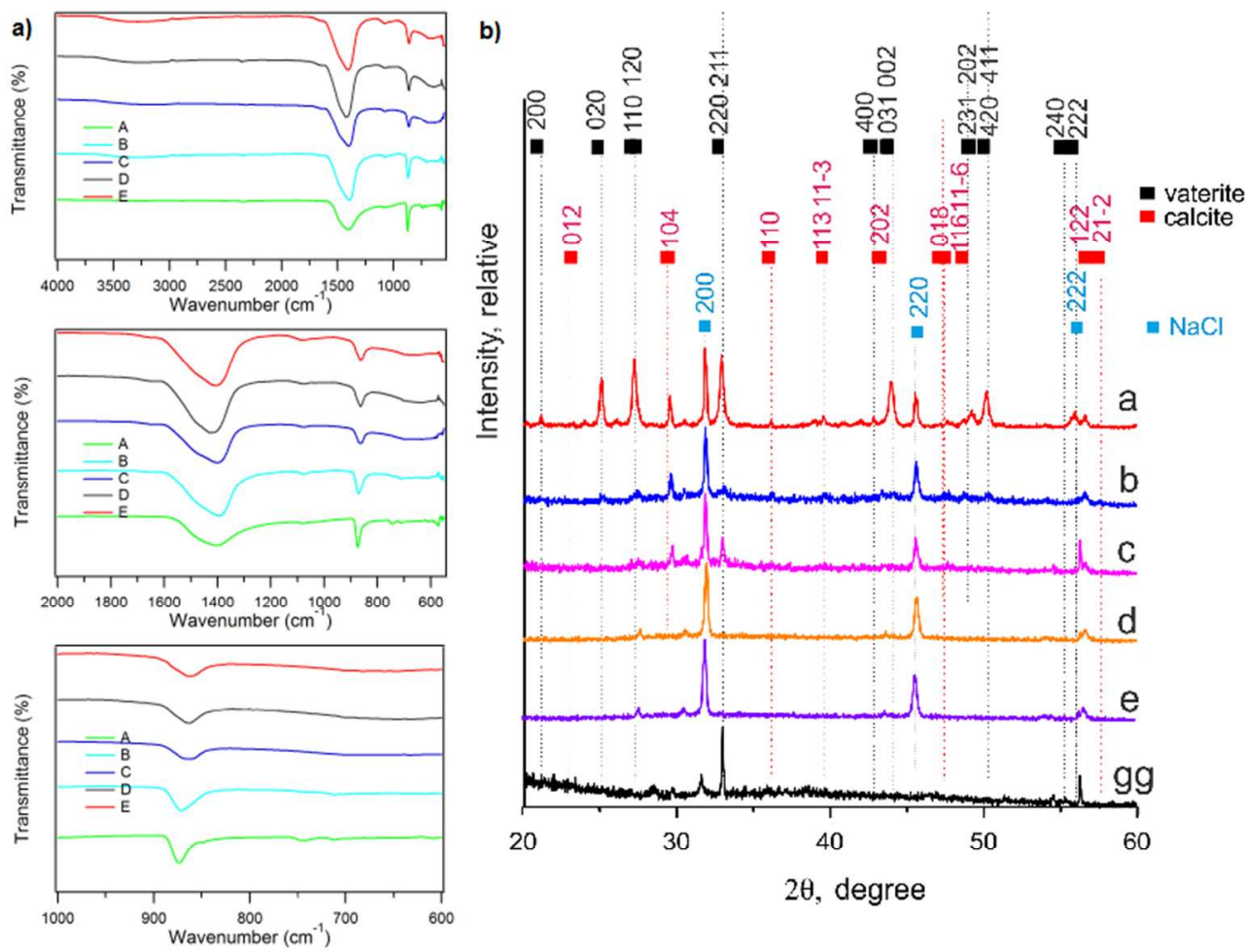

Figure 1. a) FTIR spectra of mineralized hydrogels. Top FTIR spectra from the region of 4000 to $500 \mathrm{~cm}-1$. Middle region of 2000 to $500 \mathrm{~cm}-1$. Bottom region from 1000 to $600 \mathrm{~cm}-1$. b) XRD diffractograms of mineralized hydrogels for the different sample groups

$73 \times 56 \mathrm{~mm}(300 \times 300$ DPI $)$ 

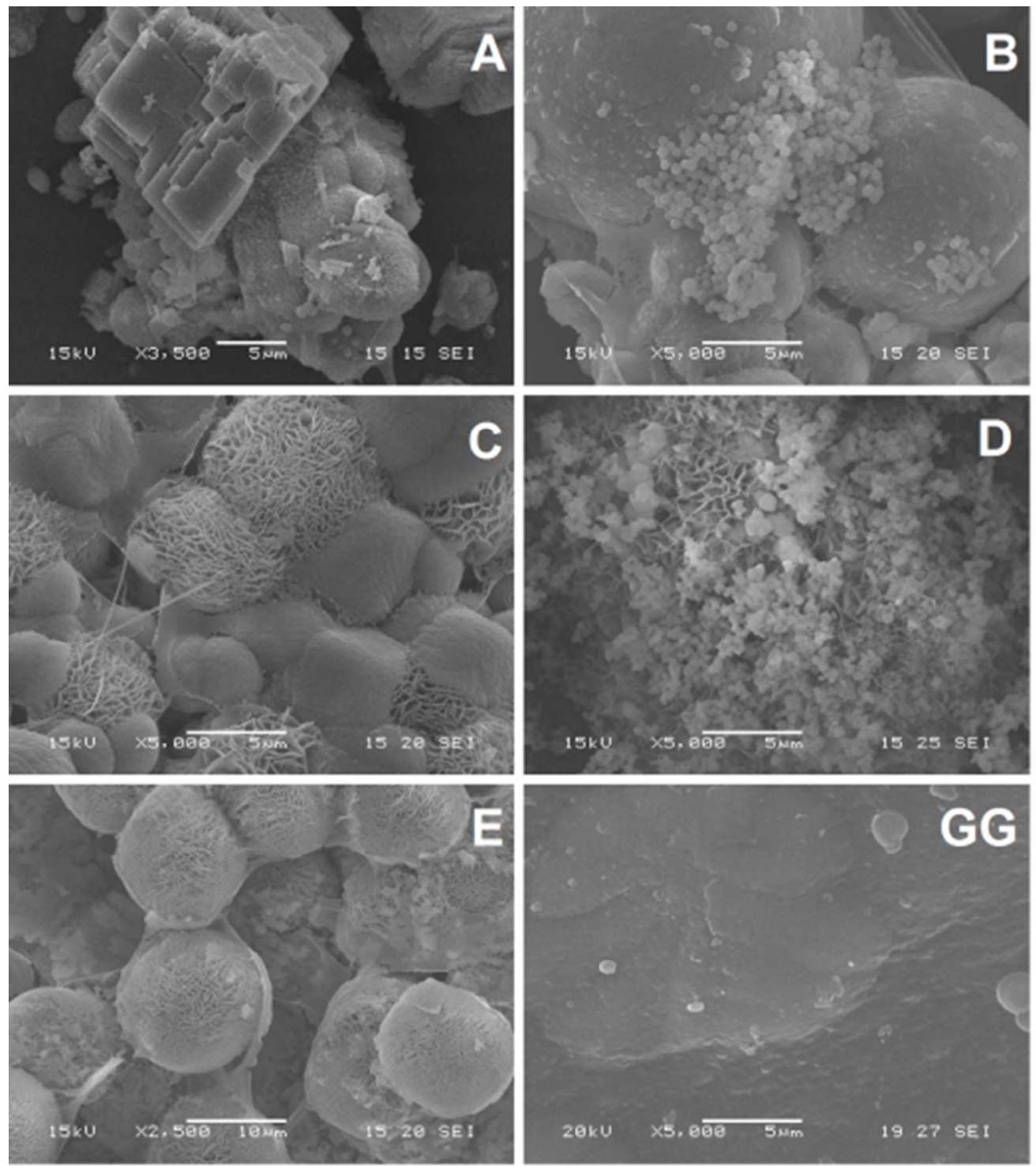

Figure 2. SEM micrographs of mineralized hydrogels. Scale bar $=5 \mu \mathrm{m}$ in all cases except $\mathrm{E}(10 \mu \mathrm{m})$. Absence of $\mathrm{Mg}$ generated a cubic structure $(\mathrm{A})$ while the presence of $\mathrm{Mg}$ created microspheres between the GG structure. Some flake -like structure can also be observed. GG alone (G) did not presented any obvious mineralization.

$44 \times 49 \mathrm{~mm}(300 \times 300$ DPI $)$ 

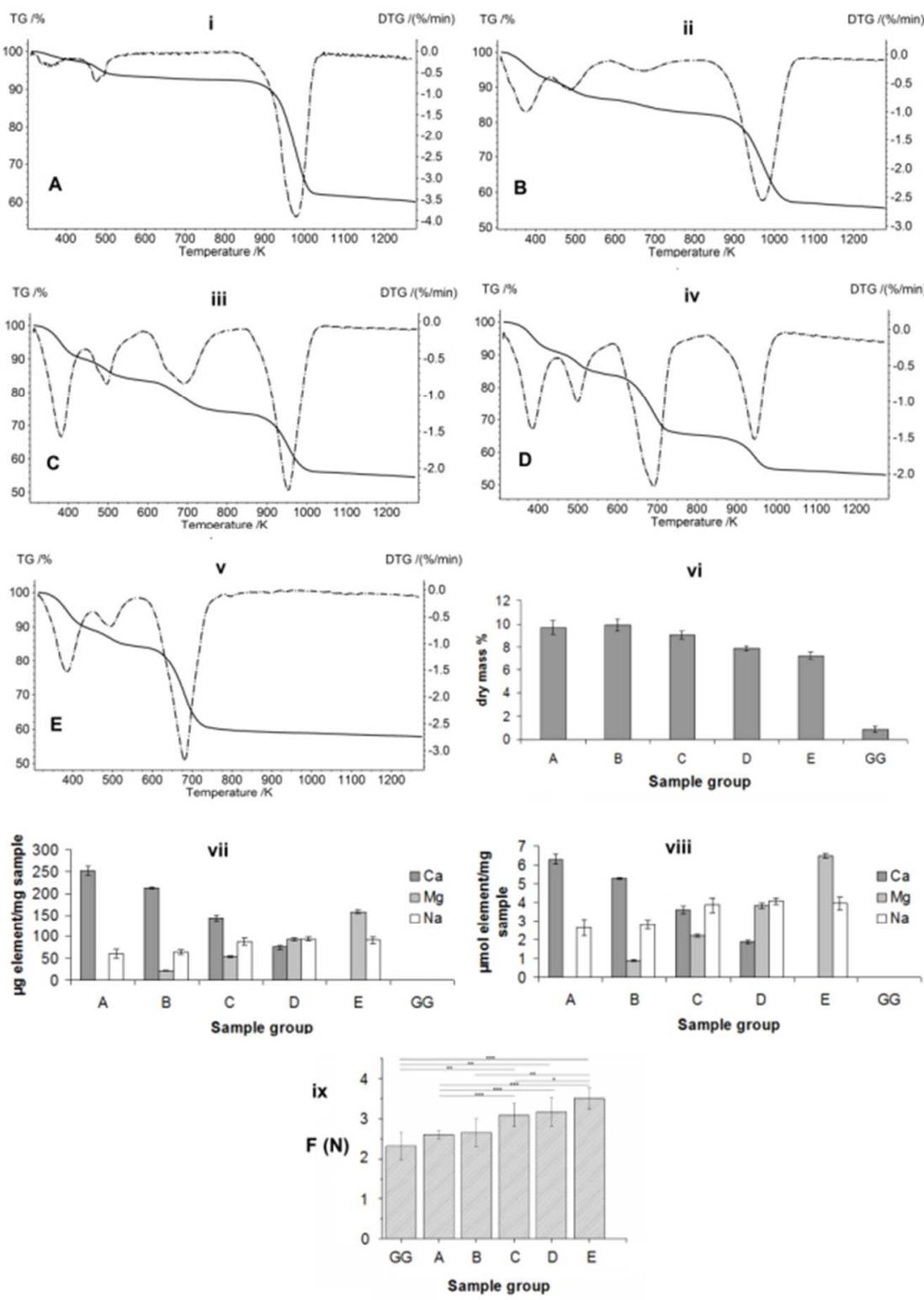

Figure 3. i-v: Thermogravimetric analysis of mineralized hydrogels A-E. Representative graphs showing residual mass percentage (TG) and rate of change of TG (DTG) are shown. vi: Dry mass percentage of mineralized (A-E) and unmineralized (GG) hydrogels. vii, viii: ICP-OES determination of elemental $\mathrm{Ca}, \mathrm{Mg}$ and $\mathrm{Na}$ present in mineralized hydrogels after drying. $\mu \mathrm{g}$ element (vii) and $\mu \mathrm{mol}$ element (viii) are shown. ix: Compressive testing of mineralized hydrogels. $y$-axis: force required to compress samples by $80 \%$. Error bars show standard deviation. Significances: *: $p<0.05 ; * *$ : $p<0.01 ; * * *$ : $p<0.001$.

$57 \times 77 \mathrm{~mm}(300 \times 300 \mathrm{DPI})$ 


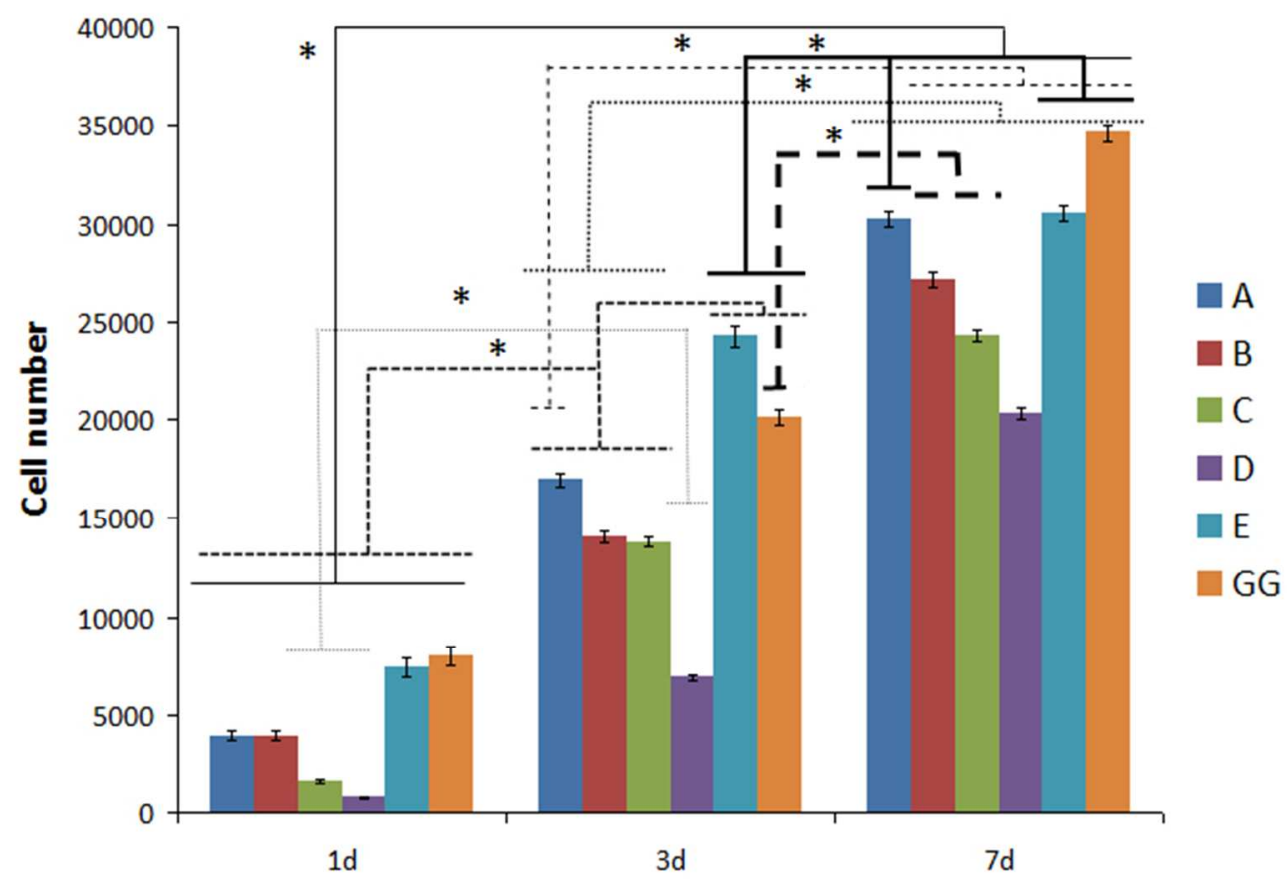

Figure 4. Proliferation of MC3T3-E1 osteoblast-like cells on mineralized (A-E) and unmineralized (GG) hydrogels. Error bars show standard deviation. Significances: $*: p<0.05, * *: p<0.01, * * *: p<0.001$.

$57 \times 40 \mathrm{~mm}(300 \times 300$ DPI $)$ 

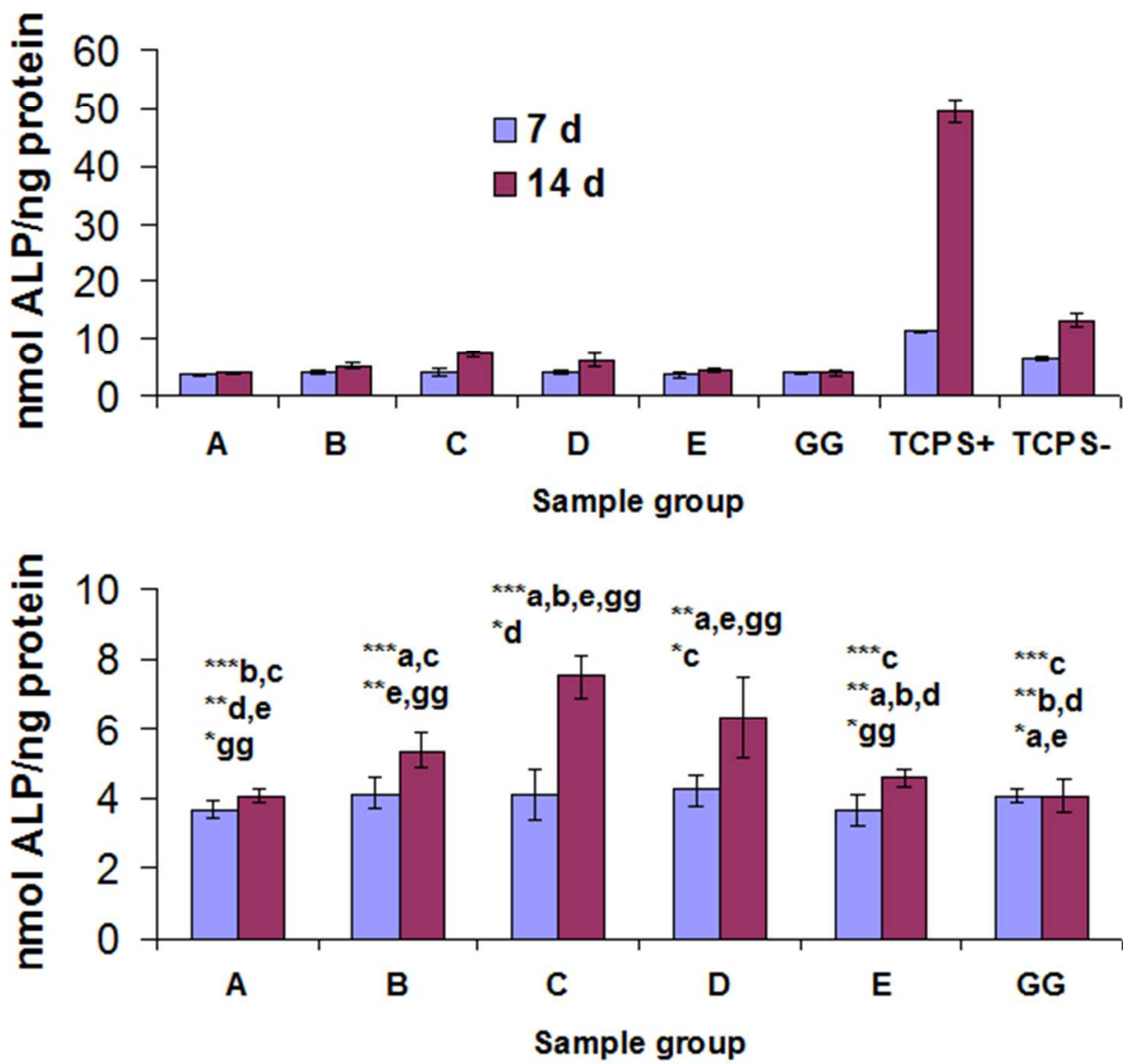

Figure 5. Osteogenic differentiation of MC3T3-E1 osteoblast-like cells on mineralized (A-E) and unmineralized (GG) hydrogels expressed as nmol alkaline phosphatase (ALP)/ng protein after 7 and 14 days. TCPS+: Tissue Culture Polystyrene with osteogenic differentiation medium. TCPS-: Tissue Culture Polystyrene without osteogenic differentiation medium. Error bars show standard deviation. Significances after $14 \mathrm{~d}: *: \mathrm{p}<0.05, * *: \mathrm{p}<0.01, * * *: \mathrm{p}<0.001$. Statistical significance between groups A-E and GG are indicated by letters. TCPS + and TCPS- were statistically different to all samples group after both 7 and 14 days. No statistically significant differences were observed between groups A-E and GG after 7 days.

$52 \times 48 \mathrm{~mm}(300 \times 300$ DPI $)$ 